\title{
Assessment of emergency consequences and hazardous factors impact from the process of explosive conversion products and materials disposal
}

\author{
Vasyl Holinko ${ }^{1}$, Yevhen Ustymenko ${ }^{2}$, Volodymyr Bondarenko ${ }^{1}$, and Iryna Kovalevska ${ }^{1 *}$ \\ ${ }^{1}$ Dnipro University of Technology, 19 Yavornytskoho Ave., 49005 Dnipro, Ukraine \\ ${ }^{2}$ Scientific and Production Association "Pavlohrad Chemical Plant", 44 Zavodska Ave., 51402 \\ Pavlohrad, Ukraine
}

\begin{abstract}
Purpose is development of tools for assessing the emergency hazard of facility for disposal of explosive conversion products and materials. Results have been obtained by means of the economic and mathematical modelling methods, with use of the fundamental provisions of probability theory. The main task of conversion products and materials disposal is the creation and organization of safe technological processes aimed at returning the material resources contained in the conversion products to the state's economy after the appropriate processing, rather than at destroying these resources. As a methodological basis for assessing the emergency hazard of a facility, a provision has been accepted that an integral measure of the disposal process hazard is the economic assessment of accidents. A scheme has been constructed of successiveness of the disposal facility events and states that can lead to an accident, on the basis of which a probabilistic model of its occurrence is developed. Proposed probabilistic model of an accident initiation at the facility for disposal of explosive conversion products and materials makes it possible to predict the behaviour of facility, based on results of the equipment and service personnel state survey, as well as on the analysis of the environmental conditions.
\end{abstract}

\section{Introduction}

Almost all technogeneous objects represent a certain hazard to humans and the natural environment. Assessment of this hazard is extremely important for society $[1,2]$. It is necessary to perform actions aimed at reducing the level of hazard, and this can be achieved by various means. To ensure the safe operation of hazardous production facilities, the current safety normative legal acts provide for the development of Declaration of Safety.

Analysis of the existing methodological support for assessing the risk of an emergency shows that, depending on the specifics of hazardous production facilities, there are many different approaches to the assessment of the emergency risk [3, 4].

\footnotetext{
* Corresponding author: kovalevska_i@yahoo.com
} 
To overcome specified constraints, a number of researchers propose to use the expert systems with a hierarchical structure for aggregating the information in a formalized form and calculating the risk indexes according to the established algorithms. At the same time, for individual hazards analysis, it is recommended to use the currently existing well-known tested expert systems [5 7]. With this approach, the risk assessment of various emergencies arising at hazardous production facilities can be achieved using universal approaches.

The occurrence of emergencies and accidents at industrial facilities in certain sectors of industry is of a systematic nature $[8,9]$. This leads to the use of qualitatively new approaches in ensuring industrial and environmental safety [10 - 12], One way to implement this approach is the method of spatial risk assessment [12]. Therewith, based on the results of statistical analysis, mathematical modelling and professional evaluation, the procedure of forming the linguistic variables and production rules of fuzzy inference is performed.

The studied models are highly adaptable to the tasks of analysing the risk of emergencies at various hazardous production facilities and are widely used in practice [13 - 15].

Purpose of our research is to develop the toolkit for assessing the emergency hazard of facilities at which the explosive conversion products and materials are disposed.

\section{Statement of basic materials}

One of the main tasks of the conversion products and materials disposal is the creation and organization of safe technological processes aimed not at destroying the material resources contained in solid-fuel missiles and ammunition, but at returning them to the state economy.

Fuel Disposal Facility (FDF) is a complex production system with particularly dangerous working conditions, where unexpected or sudden changes in conditions, failure to comply with safety regulations, or incorrect actions of employees can lead to serious consequences in some cases accompanied by numerous human victims and causing damage to the environment.

There are functional relations between the emergency processes parameters and FDF parameters. Failure to consider these relations leads to significant errors in assessing the selected disposal methods. The assessment of hazardous phenomena by socio-economic damage should be accepted as a priority. And the assessment of the effectiveness of measures and systems for emergency protection should be accepted by economic and social effects of their implementation.

The process of Solid-Propellant Fuel (SPF) disposal is determined by a combination of a significant number of hazardous and harmful factors that cannot be united and compared with each other using physical parameters. In this situation, a single solution may be their unification through economic indicators [16]. Given the fact, that the arising the emergencies caused by the influence of hazardous production factors is of probabilistic nature, the economic assessment of these phenomena should take into account the expected economic losses in case of emergencies $M\left(U_{i}\right)$ and the probabilistic nature of these phenomena occurrence [16]. Hence, the economic assessment of the $i$-th type of emergency at the facility will be as follows

$$
A_{i}=p_{i} M\left(U_{i}\right)
$$

where $p_{i}$ is probability of the $i$-th type emergency occurrence at the facility.

As an object in this case may be a storage facility for products containing SPF, a site, an installation, a complex, FDF as a whole and the like. The choice of an object depends on the purposes and objectives of assessment, as well as the availability of reliable information on the expected value of losses from emergencies and the probability of their occurrence.

For a group of objects of the same type, for example, storage facility for products containing $\mathrm{SPF}$, the economic assessment of the $i$-th type of emergency 


$$
A_{g}=\left[1-\left(1-p_{i}\right)^{k}\right] M\left(U_{i}\right),
$$

where $k$ is the number of objects of the same type.

Due to the fact that such phenomena as fire, explosion, emergency emission of toxic substances, alongside with the dangerous impact on human, they destroy or damage material assets, the expected economic losses $M U$ ) consist of direct damages to FDF together with surrounding buildings and structures, expenses for repair and restoration of facilities, material damage resulting from loss of life and injury to people (for the entire period of payments in accordance with applicable law), and others.

The normative economic assessment of hazard of the similar objects or processes at FDF, employing workers, will be

$$
A_{n}=\left[1-\left(1-p_{n}\right)^{k}\right] M\left(U_{i}\right)
$$

where $p_{n}$ is normative probability of an emergency occurrence at the facility, the value of which usually amounts to $10^{-6}$.

The actual value of the economic assessment is different from the normative, since for FDF the frequency of occurring the fires, explosions, emissions $p$ is different from $p_{n}$, and the value of expected economic losses in case of arising emergency $M U$ ) for this its type will be unchanged.

It is a common practice to calculate the socio-economic assessment of the emergency hazard on the basis of existing statistical and departmental reporting. Therewith, the general socioeconomic hazard assessment of the FDF is divided into two components:

- socio-economic assessment of emergencies;

- socio-economic assessment of accidents.

Both an emergency and an accident are the events of a random character and the methodology for their assessment should be of a general nature. Usually, the number of accidents that occurred during the year at similar technogeneous objects, is estimated in dozens. Consequently, their current and predictive assessment is performed mainly by way of mathematical processing of statistical data on the socio-economic consequences of injuries over the last period of time and by extrapolating these data to preceding time intervals [17]. The socio-economic consequences of emergencies are usually determined only by emergencies that have resulted in loss of human life or caused significant material losses, that is, in fact, by emergencies of the $1^{\text {st }}$ and $2^{\text {nd }}$ categories.

In our case, given the limited number of facilities with similar purposes in the world, as well as differences in technology and regional arrangement, such an approach to its determination is impossible. Therefore, when assessing the FDF emergency hazard, it is necessary to study the specifics of the storage and disposal processes, as well as the possible consequences of the emergency and the expected economic losses related to it.

As it follows from (1), each type of emergency has its own economic assessment, which depends on the possible economic losses in case of arising specified emergency and the probability of arising such a case. The general economic assessment of the emergency hazard of an object may ultimately be defined as follows

$$
A_{e m}=\sum_{i=1}^{n} A_{i}
$$

where $A_{i}$ is the economic assessment of the $i$-th type of emergency; $n$ is the amount of the main types of emergencies.

Equipment, machinery, structures, vessels and pipelines used at FDF have a high degree of reliability, hence, the probability of emergencies associated with their breakdown or damage according to a preliminary analysis can be taken at the level of acceptable risk, which corresponds 
to the probability of an event $10^{-6}$ per year [18]. Moreover, the expected economic losses when arising these emergencies, as a rule, are determined by the cost of specific machinery and equipment, as well as damage from the personnel injuries. The economic assessment of such emergencies, calculated according to (1), is relatively small and incomparable with the economic assessment of this type of emergency as an explosion.

The main processes, which are specified by the highest probability of an explosion, are the processes of transportation of Loaded Motor Cases (LMC), extraction and processing of SPF and the products of its disposal. However, according to (4), the existence of a large number of storages leads to a significant increase in the component of economic assessment, which is conditioned by possible emergencies arising during the storage of LMC.

The FDF security means its ability to operate trouble free under the possible influence of the following negative factors: errors when designing the FDF and manufacturing the accessory equipment; operating personnel errors; insufficient reliability of protection and systems to control the technological equipment; insufficient reliability of the system to ensure the explosion and fire safety of the object; non-conformity of characteristics of a man and technology in the system 'staffmachine-environment'; under-preparation, lack of or insufficient control over the staff work; insufficient reliability of the supporting equipment; insufficient reliability of systems related functionally with FDF; exposure to hazardous environmental factors (atmospheric electricity, flood, earthquake, etc.); low quality of planning and ensuring the technological systems operation.

When assessing the probability of arising the emergency, it is advisable to combine all the FDF equipment into groups arranged on the basis of their degree of influence on the safety of the SPF disposal process:

- elements that ensure the implementation of the production task set, reliability and safety of the SPF disposal process (processing equipment, switches, pumps);

- elements having no decisive importance for the safety and reliability (local lighting, ventilation systems, etc.).

By analogy with [19], FDF can be represented as a corresponding pattern of events and states sequences, taking into account the interaction of operating personnel, equipment and the environment (Figure 1). The normal functioning of FDF as a 'man-machine-environment' system is determined by the interaction of personnel, equipment and the environment, which are hence characterized by efficiency and operable condition.

Let us study the ways leading to each specific system state, having given preliminarily the definition of various states of personnel, equipment and environment (Table 1). The trouble free operation can be either in case of errors or physiological personnel failure, or in case of a dangerous or even extreme medium. Such exposures may lead to failure of equipment. If the defects are insignificant or are accompanied by timely repair of the equipment, as well as timely localization or liquidation of the emergency, FDF is brought to a safe state.

The corresponding probabilities of the specified modes can be written as follows $P_{S}{ }^{1}, P_{S}^{2}, P_{S}^{3}$, $P_{S}^{4}, P_{S}^{5}$ and $P_{S}^{6}$ (see Figure 1). An emergency arises in those cases when the measures taken have not lead to the localization or liquidation of the emergency situation, i.e., it is in the affected state (probability of such a phenomenon $P_{E}$ ).

Analysing the processes of storage and disposal of SPF at FDF, it is possible to draw a conclusion about the independence of the considered events, which form a complete set determining a specific situation. In such a case, the following ratios are valid:

$$
\begin{aligned}
& P_{1}+P_{2}+P_{7}=1 ; \ldots \ldots P_{3}+P_{4}+P_{5}=1 ; \\
& P_{8}+P_{9}=1 ; \ldots \ldots . . P_{10}+P_{11}=1 ; \\
& P_{12}+P_{13}=1 ; \ldots \ldots . . P_{15}+P_{16}+P_{17}=1 ; \\
& P_{18}+P_{19}+P_{20}=1 .
\end{aligned}
$$


From here it follows also that $P_{n}+P_{S}+P_{E}=1$, or

$$
P_{n}^{1}+P_{n}^{2}+P_{n}^{3}+P_{n}^{4}+P_{S}^{1}+P_{S}^{2}+P_{S}^{3}+P_{S}^{4}+P_{S}^{5}+P_{S}^{6}+P_{E}=1 .
$$

Table 1. State of the Fuel Disposal Facility

\begin{tabular}{|c|c|c|}
\hline $\begin{array}{c}\text { Number of } \\
\text { probabilities }\end{array}$ & States identification & Example of states \\
\hline$P_{1}$ & $\begin{array}{l}\text { Disease of a person - work performer, alcohol intoxication, } \\
\text { food poisoning }\end{array}$ & Faintness, hypertensive crisis \\
\hline$P_{2}$ & $\begin{array}{l}\text { Psychological antipathy of workers, incorrect occupational } \\
\text { guidance, emotional stress, claustrophobia }\end{array}$ & - \\
\hline$P_{3}$ & $\begin{array}{l}\text { Staff error that does not lead to arising any negative } \\
\text { consequences }\end{array}$ & $\begin{array}{l}\text { Switching on equipment in the } \\
\text { absence of pressure in the hydraulic } \\
\text { system }\end{array}$ \\
\hline$P_{4}$ & $\begin{array}{l}\text { Staff error that leads to violations of the technological process, } \\
\text { fixed after its correction }\end{array}$ & Wrong change over or switch off \\
\hline$P_{5}$ & $\begin{array}{l}\text { Staff error that causes equipment failure, including protective } \\
\text { devices that could lead to equipment failure }\end{array}$ & $\begin{array}{l}\text { Switching on the hydraulic monitor } \\
\text { before inserting the movable bar } \\
\text { into the engine block }\end{array}$ \\
\hline$P_{6}$ & Restoration of staff's normal state or its replacement & Providing necessary medical care \\
\hline$P_{7}$ & $\begin{array}{l}\text { Staff performance in accordance with established rules and } \\
\text { instructions }\end{array}$ & - \\
\hline$P_{8}$ & $\begin{array}{l}\text { The parameters of machinery and equipment comply with the } \\
\text { specification requirements }\end{array}$ & - \\
\hline$P_{9}$ & $\begin{array}{l}\text { The parameters of machinery and equipment have some } \\
\text { deviation from specification. }\end{array}$ & $\begin{array}{l}\text { Reducing the solution temperature } \\
\text { below the set limit }\end{array}$ \\
\hline$P_{10}$ & $\begin{array}{l}\text { Changing the parameters of machinery and equipment, } \\
\text { complicating the process of their operation }\end{array}$ & Damage to valve components \\
\hline$P_{11}$ & $\begin{array}{l}\text { Changing the parameters of machinery and equipment that is } \\
\text { able to lead to an emergency }\end{array}$ & Pipeline rupture \\
\hline$P_{12}$ & Violation of equipment operation mode & $\begin{array}{l}\text { Lack of water in the water supply } \\
\text { system }\end{array}$ \\
\hline$P_{13}$ & $\begin{array}{l}\text { Work on the restoration of good serviceability of machinery } \\
\text { and equipment }\end{array}$ & Replacing machine parts \\
\hline$P_{14}$ & $\begin{array}{l}\text { Changing the parameters of machinery and equipment leading } \\
\text { to an emergency }\end{array}$ & $\begin{array}{l}\text { Break of airtightness of vessels } \\
\text { under pressure, overheating of the } \\
\text { mechanism }\end{array}$ \\
\hline$P_{15}$ & $\begin{array}{l}\text { Exclusion from the technological process of some machinery } \\
\text { and equipment, which are in emergency condition }\end{array}$ & $\begin{array}{l}\text { Excluding the damaged vessel from } \\
\text { the technological process }\end{array}$ \\
\hline$P_{16}$ & $\begin{array}{l}\text { An event impeding the recovery of machines and equipment } \\
\text { serviceability, as well as their exclusion from the process }\end{array}$ & Fire, explosion \\
\hline$P_{17}$ & $\begin{array}{l}\text { Complete exclusion from the operation of machinery and } \\
\text { equipment in emergency condition }\end{array}$ & $\begin{array}{l}\text { Switch to water supply from a } \\
\text { backup source }\end{array}$ \\
\hline$P_{18}$ & $\begin{array}{l}\text { An environment that provides working conditions, the } \\
\text { parameters of which do not go beyond the optimal }\end{array}$ & $\begin{array}{l}\text { Optimum microclimate parameters } \\
\text { regulated by current sanitary norms }\end{array}$ \\
\hline$P_{19}$ & $\begin{array}{l}\text { An environment that provides working conditions, the } \\
\text { parameters of which do not go beyond the permissible. The } \\
\text { environment leading to the deterioration of the technical } \\
\text { characteristics of the operated machinery and equipment }\end{array}$ & $\begin{array}{l}\text { Permissible microclimate } \\
\text { parameters regulated by current } \\
\text { sanitary norms }\end{array}$ \\
\hline$P_{20}$ & $\begin{array}{l}\text { Harmful and hazardous working conditions. Extreme } \\
\text { conditions leading to pathological changes in the human body } \\
\text { and to the impossibility of performing work. The environment } \\
\text { that prevents the performance of the functions of machinery } \\
\text { and equipment or leading to the violation of their integrity }\end{array}$ & $\begin{array}{l}\text { Oversubmergence as a result of } \\
\text { flooding, gasification of FDF } \\
\text { premises with toxic gases, } \\
\text { extremely low or high ambient } \\
\text { temperature, earthquake, landslide }\end{array}$ \\
\hline
\end{tabular}

The probability model of arising the emergency at FDF, constructed in accordance with Figure 1, is represented in Figure 2.

Using the model shown in Figure 1, as well as the logical-probabilistic approach and the apparatus of conditional probabilities, denoting them by $P\left(S_{A} / S_{B}\right)$, the probability of occurrence of events $A$ provided that event $B$ has arisen, can be written as follows: 


$$
\begin{aligned}
& P_{E}=\left\{\left[P_{S}{ }^{4}+P_{1}-P\left(S_{1} \wedge S_{11} / S_{5} \Lambda S_{9} \Lambda S_{19}\right)\right] \times P\left(S_{12} / S_{11} / S_{5} \wedge S_{9} \Lambda S_{19}\right)+P_{20}-\right. \\
& \left.\quad-P\left(S_{1} \Lambda S_{20} \wedge S_{12} / S_{11} / S_{5} \wedge S_{9} \Lambda S_{19}\right)\right\} \times P\left(S_{14} / S_{12} \Lambda S_{20}\right) \times P\left(S_{16} / S_{14}\right) .
\end{aligned}
$$

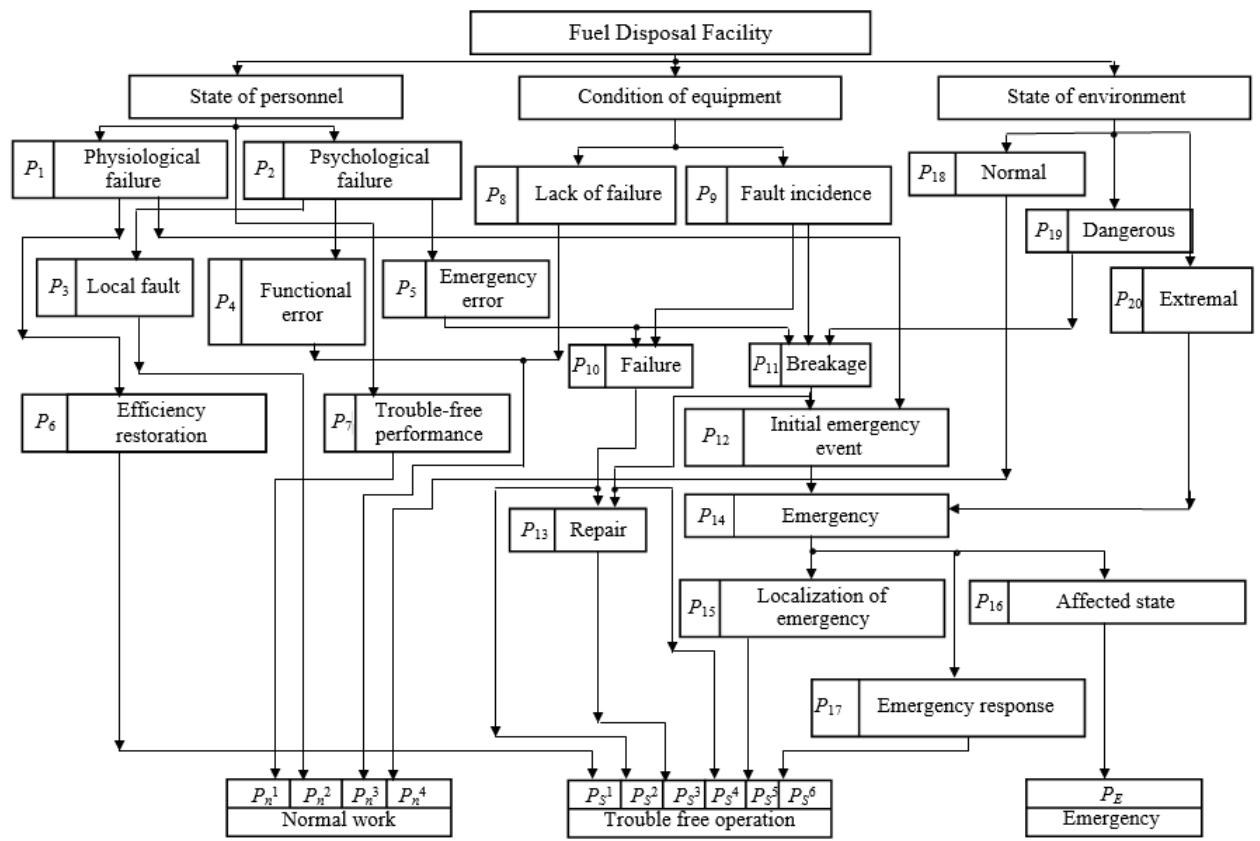

Fig. 1. Scheme of sequences of events and states.

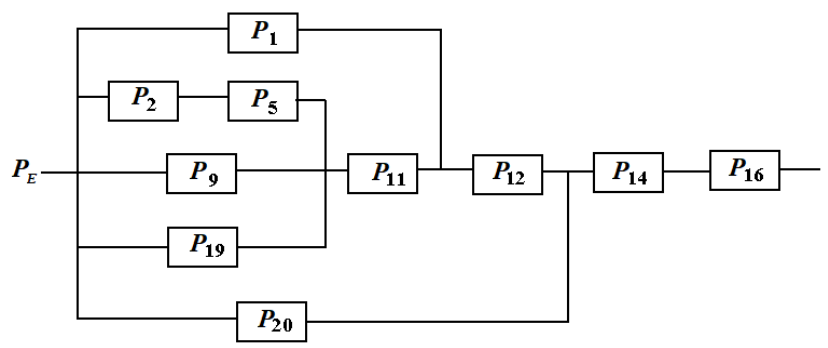

Fig. 2. Probabilistic model of an emergency arising at FDF.

The determination of the above probability of the emergency occurrence at FDF and the prediction of the facility behaviour is carried out on the basis of the inspection results of the equipment and operating personnel state, as well as an analysis of the environmental state.

In case of an increased value of probability of occurring the undesirable phenomena, for example, alarm errors $P_{5}$, failures $P_{10}$ or emergency situations $P_{14}$, it is necessary to strengthen the control over the professional selection and training of personnel, timely conducting inspections and repairs of equipment.

The FDF consideration from the 'man-machine-environment' position enables, based on a unified methodology, to assess its safe properties with subsequent rationing of the required probabilities of normal or trouble free operation of the entire facility, taking into account the actions of operating personnel and the influence of the environment. Numerical implementation of the computational scheme shown in Figure 2, requires determination of probability values, including the conditional ones, characterizing different states of the 'staff-machine-environment' system.

Given the uniqueness of the FDF, the statistics in this area does not cover most of the factors to be analysed, for example, the types of personnel errors. Therefore, the data on other factors, such as 
the state of the personnel, is of unreliable character [20]. In such cases, to determine the main parameters characterizing the work of complex technogeneous objects, it is most appropriate to use expert assessment methods [21]. These methods allow to correctly solve these problems in reliance upon a sufficiently wide and competent circle of professionals being surveyed.

It should be noted that the proposed methodology makes no possible obtaining a complete data selection, however, its use in combination with the sampling technique, provided the use of smoothing the obtained trends by known methods [22], ensures obtaining the correct results.

\section{Conclusions}

The proposed probabilistic model of an 'Explosion' type emergency arising at FDF allows predicting the facility behaviour based on the inspection results of the equipment and operating personnel state, as well as an analysis of the environmental state. Given the uniqueness of the FDF and the lack of statistical data on most of factors to be analysed, the expert assessment method is proposed to use when determining the main parameters characterizing the FDF operation. The following provision has been adopted as a methodological basis for assessment of an emergency hazard of FDF: an integral measure of the technological process hazard of SPF disposal is the economic assessment of emergencies typical of this process or production. Given the fact, that the occurrence of emergencies caused by the influence of hazardous production factors is of probabilistic nature, the economic assessment of these phenomena takes into account the expected economic losses in case of emergencies and the probabilistic nature of their occurrence.

\section{References}

1. V. Bondarenko, I. Kovalevs'ka, V. Fomychov, Geomechanical Processes during Underground Mining: School of Underground Mining 2012, 7-13 (2012)

2. V.I. Bondarenko, G.A. Simanovich, I.A. Kovalevska, V.V. Fomichov, V.P. Serdiuk, Techn., Technol. and Econ. Asp. of Thin-Seams Coal Mining: Intern. Mining Forum 2007, 47-56 (2007)

3. S. Kabir, Y. Popadopoulos, Safety Science 115, 154-175 (2019)

4. I. Shabtai, E. Tsah, Automation in Construction 63, 66-78 (2016)

5. M. Sarbayev, M. Yang, H. Wang, J. of Loss Prevention in the Proc. Ind. 60, 203-212 (2019)

6. S.V. Myasnikov, G.I. Korshunov, E.I. Kabanov, Occupational Safety in Industry 5, 60-65 (2018)

7. M. Yazdi, P. Hafezi, R. Abbasi, J. of Loss Prevention in the Proc. Ind. 58, 51-59 (2019)

8. I. Kovalevska, G. Symanovych, V. Fomychov, Ann. Sc. And Tech. Coll. - Mining of Mineral Deposits 2013, 159-163 (2013)

9. V.I. Bondarenko, Ye.N. Kharin, N.I. Antoshchenko, R.L. Gasyuk, Naukovyi Visnyk Natsionalnoho Hirnychoho Universytetu 5 (2013)

10. E.V. Kireeva, M.S. Kireev, Intern. J. of Applied Eng. Res. 12 (16), 5463-5471 (2017)

11. S.P. Voronov, A.V. Matushin, M.M. Shlepenev, Bulletin of St. Petersburg State Fire Service University of EMERCOM of Russia 1, 130-140 (2016)

12. E.I. Kabanov, Mining Informational and Analytical Bulletin 4, 78-86 (2019)

13. G.K. Koulinas, P.K. Marhavilas, O.E. Demesouka, Safety Science 112, 96-104 (2019)

14. R. Nourian, S.M. Mousavi, S. Raissi, J. of Loss Prevention in the Proc. Ind. 59, 77-90 (2019)

15. A.G. Urbina, A. Aoyama, J. of Loss Prevention in the Proc. Ind. 45, 116-132 (2017)

16. O. Vagonova, V. Arzhevichev, O. Cherkashchenko, Energy Saving and Efficiency: Advanced Engineering Forum 2017 25, 64-70 (2017)

17. O.H. Vahonova, L.V. Kasianenko, Ekonomichnyi visnyk NHU 1 (2013)

18. E.D. Khenli, Kh. Kumamoto, Nadezhnost' tekhnicheskikh sistem $i$ otsenka riska (Mashinostroenie, Moskva, 1984)

19. V.F. Stoetskyi, V.Y. Holynko, L.V. Dranyshnykov, Naukovyi visnyk NHU 3,117-124 (2014)

20. V.I. Golin'ko, L.N. Shiman, E.B. Ustimenko, Bezopasnost' protsessov utilizatsii raketnykh dvigateley tverdogo topliva (Lira LTD, Dnepropetrovsk, 2011)

21. A.M. Bryukhanov, Nauchno-tekhnicheskie osnovy rassledovaniya i predotvrashcheniya avariy na ugol'nykh shakhtakh (Donbass, Donetsk, 2004)

22. Dzh. T'yuki, Analiz rezul'tatov nablyudeniy (Mir, Moskva, 1989) 